\title{
Impact of isotype-selective estrogen receptor agonists on ovarian function
}

\author{
Christa Hegele-Hartung*`, Philip Siebel*, Olaf Peters ${ }^{\ddagger}$, Dirk Kosemund ${ }^{\ddagger}$, Gerd Müller ${ }^{\ddagger}$, Alexander Hillisch\$, \\ Alexander Walter*, Jörn Kraetzschmar*, and Karl-Heinrich Fritzemeier*
}

*Schering AG, Müllerstrasse 170-178, D-13342 Berlin, Germany; ${ }^{\ddagger}$ Jenapharm GmbH and Co. KG, Otto-Schott-Strasse 15, D-07745 Jena, Germany; and
§EnTec Gesellschaft für Endokrinologische Technologie mbH, Adolf-Reichwein-Strasse 20, D-07745 Jena, Germany

Edited by Jan-Åke Gustafsson, Karolinska Institute, Huddinge, Sweden, and approved January 22, 2004 (received for review October 16, 2003)

Other isotype-selective estrogen receptor (ER) agonists, the selective $E R \alpha$ agonist 3,17-dihydroxy-19-nor-17 $\alpha$-pregna-1,3,5 (10)triene-21,16 $\alpha$-lactone and the selective ER $\beta$ agonist 8-vinylestra1,3,5 (10)-triene-3,17 $\beta$-diol, were used in hypophysectomized rats, gonadotropin-releasing hormone antagonist-treated mice, as well as intact rats to elucidate the effects of isotype-selective estrogens on the physiology of folliculogenesis and ovulation. In hypophysectomized rats and gonadotropin-releasing hormone antagonisttreated mice, the ER $\boldsymbol{\beta}$ agonist caused stimulation of early folliculogenesis, a decrease in follicular atresia, induction of ovarian gene expression, and stimulation of late follicular growth, accompanied by an increase in the number of ovulated oocytes similar to $17 \beta$-estradiol (E2). In contrast, the ER $\alpha$ agonist had little or no effect on these parameters, implying that direct estrogen effects on ovarian follicular development are mediated by ERß. In intact rats, E2 and the ER $\alpha$ agonist dose-dependently inhibited ovulation, in contrast to the ER $\beta$ agonist. On the other hand, the ER $\beta$ agonist did not stimulate uterine weight in intact rats, in contrast to E2 and the ER $\alpha$ agonist. This finding is in line with the assumption that estrogen mediated ovulation inhibition and stimulation of uterine growth are mediated by ER $\alpha$ but not by ER $\beta$.

pharmacology | folliculogenesis | endocrinology

E strogens play a central role in the development and maintenance of female reproductive organs, mammary glands, and sexual behavior. In addition, estrogen's involvement in the function of a number of other tissues such as the bone, the cardiovascular, and the CNS has also been recognized $(1,2)$.

Estrogens exhibit most of their physiological effects through nuclear receptor proteins, the estrogen receptors (ERs). Until recently, it had been assumed that there is only one ER. In 1996, a second ER was detected (3-5), which shares a high degree of homology with the "classic" counterpart, specifically in the DNA- and ligand-binding domains. The newly detected receptor is called $\operatorname{ER} \beta$, the classic counterpart being renamed as $\operatorname{ER} \alpha$. The expression pattern of the two ER isotypes is different: $\mathrm{ER} \beta$ is predominantly expressed in the ovary and prostate but also other organs not subserving reproduction-related functions. In contrast, its expression is low in the pituitary, the thymus, the uterus, and the liver; these organs express ER $\alpha$ at high levels (6, 7). A distinct tissue distribution of $\operatorname{ER} \alpha$ and $\operatorname{ER} \beta$ suggests specific biological functions of $\mathrm{ER} \alpha$ and $\mathrm{ER} \beta$.

$\mathrm{ER} \beta$ is the predominant ER in ovarian follicles in rodents and nonrodents (8-10). The hypothesis that ER $\beta$ plays an important role in the control of ovarian function is supported by data from various lines of $\operatorname{ER} \beta$ knockout mice showing different degrees of female subfertility due to reduced follicular maturation and ovulation rate (11).

The stimulatory activity of estrogens on ovarian cell growth, especially folliculogenesis, has been demonstrated in rodent models $(12,13)$. It is suggested that estrogens enhance the effects of follicle-stimulating hormone on gene expression in granulosa cells (14). Follicle-stimulating hormone causes induction of insulin-like growth factor I, which was shown to regulate the level of $\operatorname{ER} \beta$.

Recently, highly selective ER isotype selective agonists were identified (15-17). The studies shown in the present paper have been performed with the novel highly selective steroidal ER $\beta$ agonist $8 \beta$-VE2 (18), and the highly selective $\mathrm{ER} \alpha$ agonist $16 \alpha$-LE2 (Fig. 1), which belong to the most potent and isotypeselective estrogens identified so far. In vitro, the $\operatorname{ER} \beta$ agonist $8 \beta-\mathrm{VE}_{2}$ is characterized by 190 -fold higher relative potency in $\mathrm{ER} \beta$ compared with $\mathrm{ER} \alpha$-dependent transactivation assays. The selectivity is also documented by receptor-binding studies showing 93 (rat)- and 180 -fold (human) preference for ER $\beta$. The ER $\alpha$ agonist $16 \alpha-\mathrm{LE}_{2}$ is characterized by 265 -fold higher relative potency in $\mathrm{ER} \alpha$ compared with $\mathrm{ER} \beta$-dependent transactivation assays. The selectivity is also documented by receptor binding studies showing 70-fold (rat and human) preference for ER $\alpha$.

The identification of isotype-selective ER ligands provides an alternative approach to studying the biological role of $\operatorname{ER} \alpha$ and $\mathrm{ER} \beta$ to those of ER knockout animals. $\mathrm{ER} \beta$ specific agonists are expected to exhibit estrogen-like effects in tissues expressing predominantly $\mathrm{ER} \beta$, like the granulosa cells of the ovary, but to cause little or no estrogen-like effects in tissues expressing predominantly $\mathrm{ER} \alpha$, like the uterus. In the present study, the effects of isotype-selective ER ligands on ovarian and uterine biology as well as ovarian gene expression were investigated. By controlling the dose of selective stimulation of one ER isotype, we were aiming to add more insights into the complicate interpretation of studies with ER knockout animals.

\section{Materials and Methods}

Animals and Drugs. All animal procedures were run according to German animal welfare law with the permission of the District Government of Berlin. Mice (NMRI, Schönwalde, Germany) and rats (Wistar Hannover, Schering AG, Berlin, Germany) were maintained on a 14-h light/10-h dark cycle and were provided with food and water ad libitum.

All animal studies were performed with E2, the selective ER $\alpha$ agonist 3,17-dihydroxy-19-nor-17 $\alpha$-pregna-1,3,5 (10)-triene$21,16 \alpha$-lactone $\left(16 \alpha-\mathrm{LE}_{2}\right)$, and the selective $\operatorname{ER} \beta$ agonist 8vinylestra-1,3,5 (10)-triene-3,17 $\beta$-diol $\left(8 \beta-\mathrm{VE}_{2}\right)$. All compounds were provided by the Schering Group.

Experimental protocols. Effects on early folliculogenesis in hypophysectomized (hx) juvenile rats. Twenty-four-day-old female rats (body weight, $50 \mathrm{~g}$ ) were hx on day 0 and were treated s.c. for 4

This paper was submitted directly (Track II) to the PNAS office.

Abbreviations: E2, $17 \beta$-estradiol; ER, estrogen receptor; hx, hypophysectomized; $16 \alpha-\mathrm{LE}_{2}$, 3,17-dihydroxy-19-nor-17 $\alpha$-pregna-1,3,5 (10)-triene-21,16 $\alpha$-lactone; $8 \beta$-VE $\mathrm{V}_{2}$, 8-vinylestra1,3,5 (10)-triene-3,17 $\beta$-diol; GnRH, gonadotropin-releasing hormone; hCG, human chorionic gonadotropin; PMSG, pregnant mare serum gonadotropin; $\mathrm{AMH}$, anti-Mullerian hormone; TUNEL, terminal deoxynucleotidyltransferase-mediated dUTP nick end labeling; CRABPII, cellular retinoic acid binding protein II; ALFUC, $\alpha$-L-fucosidase; PGIS, prostacyclin synthase; LH, luteinizing hormone.

${ }^{\dagger}$ To whom correspondence should be addressed at: Schering AG, Müllerstrasse 170, D-13342 Berlin, Germany. E-mail: christa.hegelehartung@schering.de.

(C) 2004 by The National Academy of Sciences of the USA 

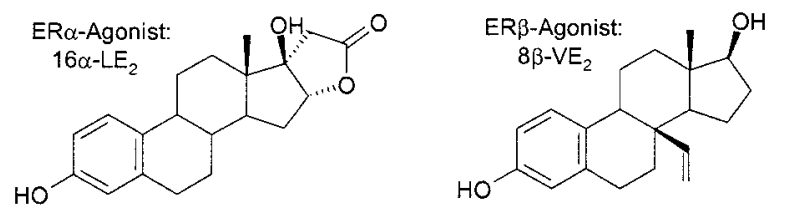

Fig. 1. Structure of highly selective steroidal ER isotype-selective agonists.

consecutive days (days 6-9) daily with $\mathrm{E} 2,16 \alpha-\mathrm{LE}_{2}$, and $8 \beta-\mathrm{VE}_{2}$ at doses of $0.01,0.1$, and $1 \mathrm{mg}$ per animal, respectively. Control animals were treated with the respective vehicle. On day 10 , ovaries and uteri were removed and weighed (relative wet weight in $\mathrm{mg}$ per $100 \mathrm{~g}$ of body weight). Each group consisted of six animals.

Effects on early folliculogenesis in gonadotropin-releasing hormone (GnRH) antagonist-treated juvenile mice. Twenty-day-old mice (body weight: $10 \mathrm{~g}$ ) were i.p. injected daily for 8 days with the GnRH antagonist cetrorelix (50 $\mu \mathrm{g}$ per animal) to suppress secretion and release of gonadotropines. The day of first injection was designated as day $0 . \mathrm{E} 2,16 \alpha-\mathrm{LE}_{2}, 8 \beta-\mathrm{VE}_{2}$ were injected s.c. at a dose of $0.3 \mathrm{mg}$ per animal, respectively, on days $4,5,6$, and 7 . Control animals received the respective vehicle. On day 8, ovaries and uteri were removed and weighed (relative wet weight in $\mathrm{mg}$ per $10 \mathrm{~g}$ of body weight). Each group consisted of five animals.

Effects on late follicular development and ovulation rate in hx juvenile rats. As described above, hx juvenile rats were treated s.c. for 4 days daily with vehicle, $\mathrm{E} 2,16 \alpha-\mathrm{LE}_{2}$, or $8 \beta-\mathrm{VE}_{2}$ at doses of 0 (vehicle), $0.01,0.1$, and $1 \mathrm{mg}$ per animal, respectively. One day later (day 10 ), pregnant mare serum gonadotropin (PMSG) at a dose of 20 units was s.c. injected to stimulate late follicular development. Ovulation was induced 2 days later (day 12) by an i.p. injection of 10 units of human chorionic gonadotropin (hCG). One day after hCG injection, the ovaries and the fallopian tubes were isolated. Ovarian weight was determined (relative wet weight in mg per $100 \mathrm{~g}$ of body weight). Ovulation rate, defined by the number of oocytes in the oviduct, was determined after flushing the fallopian tubes with saline. Each group consisted of five to seven animals.

Effects on ovulation rate in adult, intact rats. Adult female rats (9-11 weeks old; body weight, $200 \mathrm{~g}$ ) showing regular 4-day cycles in the previous 8 days were used in this study. Starting in metestrus they were s.c. treated daily for 4 days with vehicle, E2, $16 \alpha-\mathrm{LE}_{2}$, or $8 \beta-\mathrm{VE}_{2}$ at doses of $0.1,1,10,100$ and $1,000 \mu \mathrm{g}$ per rat, respectively. On the next day, the uteri and the fallopian tubes were isolated. Uterus weight was determined after drying for $5 \mathrm{~h}$ at $50^{\circ} \mathrm{C}$ (relative dry weight in $\mathrm{mg}$ per $100 \mathrm{~g}$ of body weight). Ovulation rate, defined by the number of oocytes in the oviduct, was determined after flushing the fallopian tubes with saline. Each group consisted of eight animals.

Histology and Immunohistochemistry. Histology and immunohistochemistry were performed on ovaries taken from juvenile hx rats and juvenile $\mathrm{GnRH}$ antagonist-treated mice treated with vehicle, E2, $8 \beta-\mathrm{VE}_{2}$, and $16 \alpha-\mathrm{LE}_{2}$, as described above. On days 10 (rats) and 8 (mice), 1 day after the last treatment, ovaries were fixed in $3.7 \%$ neutral buffered formalin and were embedded in paraffin. Sections $(5 \mu \mathrm{m})$ were stained with hematoxylin/eosin.

Immunohistochemical analysis was performed on ovarian paraffin sections by using the labeled streptavidin-biotin complex immunoperoxidase method (19) with primary antibodies specific for proliferating cell nuclear antigen (mAb: PC-10, DakoCytomation, Glostrup, Denmark; ready for use), $\operatorname{ER} \alpha$ (mAb: 1D5, DakoCytomation; ready for use), ER $\beta$ (polyclonal rabbit antibody: 310B, Dianova, Hamburg, Germany; dilution: 1:300), Inhibin $\alpha$ (mAb: R1, Oxford Bio-Innovation, Ltd., Ox- fordshire, U.K.; dilution: 1:100), and anti-Mullerian hormone (AMH) (polyclonal goat antibody: C-20, Santa Cruz Biotechnology; dilution: 1:1,000). The omission of the first antibody was used as the negative control. Slides were evaluated in areas with well preserved tissue morphology independently by two observers. Immunoreactivity was graded from "negative," "weakly positive," "moderately positive," to "strongly positive." Every stained cell was considered as positive, irrespective of intensity.

Detection of Apoptosis. Investigations were performed on ovaries taken from animals treated for early folliculogenesis experiments. The investigations were performed 1 day after the last treatment with the respective compounds. Apoptotic cells and bodies were detected on formaldehyde fixed and paraffin embedded sections by the terminal deoxynucleotidyltransferasemediated dUTP nick end labeling (TUNEL) assay as described (20). Positive TUNEL controls were run by incubating sections with DNase (Stratagene) after the permeabilization step. Negative controls for the TUNEL staining were made by omitting terminal deoxynucleotidyltransferase from the labeling mixture.

Follicle Staging and Ovarian Gene Regulation. Follicle staging. Serial hematoxylin/eosin stained sections $(5 \mu \mathrm{m})$ of both ovaries from juvenile GnRH antagonist-treated mice were used for follicle counting and staging in early folliculogenesis experiments. Every fifth section was analyzed on a photomicroscope and follicles were counted when the nucleus of the oocyte was visible. Follicle staging was performed according to Pederson and Peters (21). Briefly, ovarian follicles were divided into primary follicles containing one layer of flattened (type 3a) or cuboidal (type 3b) granulosa cells, secondary follicles containing two layers (type 4 ), preantral follicles containing more than two layers (types 5a and $5 \mathrm{~b}$ ) and antral follicles containing several layers of granulosa cells and fluid filled spaces (types 6, 7, and 8). Nonatretic and atretic follicles were counted separately. The criteria for atresia were the presence of pyknotic nuclei in the granulosa cells and/or degeneration of the nucleus of the oocyte.

Affymetrix microarray. To identify genes regulated by $8 \beta-\mathrm{VE}_{2}$ and $16 \alpha-\mathrm{LE}_{2}$, a high-density oligonucleotide Affymetrix microarray, Rat Genome U34A (22), was used for expression analysis. The fluorescence intensities for the individual oligonucleotide probes on the arrays were determined with a confocal scanner. The expression ratio for an individual gene between two arrays ("pairwise comparison") was derived from the distribution of the apparent perfect-match (PM) and mismatch (MM) expression ratios $\left[R=\left(\mathrm{PM}_{\mathrm{I}}-\mathrm{M}_{\mathrm{I}}\right) /\left(\mathrm{PM}_{\mathrm{II}}-\mathrm{MM}_{\mathrm{II}}\right)\right]$ calculated individually from the perfect-match-mismatch differences for each oligonucleotide detector, taking into account only those probe pairs for which the perfect-match signal exceeded the mismatch signal on both arrays compared. Genes were then ranked according to most coherent behavior over multiple pairwise comparisons, by using a proprietary software tool. Comparisons were made between vehicle-treated and E2-, $8 \beta$ $\mathrm{VE}_{2-}$, or $16 \alpha-\mathrm{LE}_{2}$-treated tissue, with vehicle representing the baseline measurement. A gene in the treated animals was considered induced or repressed whether $(i)$ the normalized average difference value was above the background value of the GeneChip and (ii) the fold change exceeded 2.5 in either direction (i.e., induced or repressed).

Northern blot analysis/RT-PCR. The expression level of selected genes known to be expressed in the ovary was analyzed by Northern blot analysis or by real-time quantitative PCR (Table 2, which is published as supporting information on the PNAS web site) using SYBR green and an ABI PRISM 7700 sequence detection system. Relative quantification was performed by using the comparative method with GAPDH as an endogenous control. 

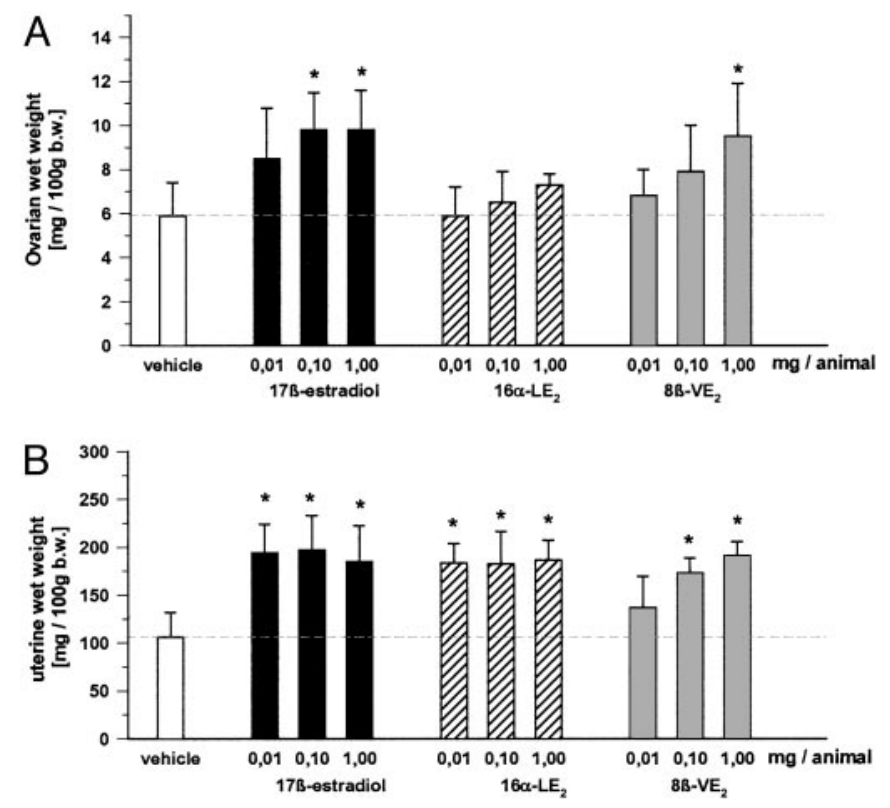

Fig. 2. Effect of vehicle, E2, $8 \beta-\mathrm{VE}_{2}$, and $16 \alpha-\mathrm{LE}_{2}$ on ovarian wet weight $(A)$ and uterine wet weight $(B)$ in $h x$ juvenile rats. Vehicle and compounds were s.c. administered daily for 4 days ( $n=6$ animals per group). *, $P<0.05$ vs. vehicle group. Values are given as mean \pm SD.

Statistical Analysis. One-way ANOVA was used to demonstrate statistical differences between groups. A $P$ value of $<0.05(5 \%$ significance level) was considered statistically significant. Windows statistical software SIGMASTAT V2.0 (Jandel Scientific) was used.

\section{Results}

Effects on Early Folliculogenesis in hx Juvenile Rats and GnRH Antagonist-Treated Mice. Ovarian and uterine wet weights. In hx rats, a dose-dependent increase in ovarian weights was observed after $\mathrm{E} 2$ and $8 \beta-\mathrm{VE}_{2}$ treatment, reaching significance at 0.1 and $1 \mathrm{mg}$ per animal. In contrast, $16 \alpha-\mathrm{LE}_{2}$ did not stimulate ovarian weights (Fig. 2). At all doses tested, E2 and $16 \alpha-\mathrm{LE}_{2}$ caused full stimulation of uterine growth. Stimulation of uterine growth was less pronounced in the $8 \beta-\mathrm{VE}_{2}$-treated animals and started at 0.1 mg per animal.

Ovarian histology, TUNEL, and immunohistochemistry. To determine the reason for the increase in ovarian weight caused by E2 and $8 \beta-\mathrm{VE}_{2}$, ovaries were removed and were prepared for histology. Compared with the vehicle group, no difference was observed regarding follicle size and atresia in all $16 \alpha-\mathrm{LE}_{2}$-treated animals. Most of the preantral follicles were small and atretic. In E2- and $8 \beta-\mathrm{VE}_{2}$-treated animals, the ovaries showed only few atretic preantral follicles. As an indication for stimulation of early folliculogenesis, there was a clear increase in the size of preantral follicles, starting at $0.01 \mathrm{mg}$ per animal in E2 and at $0.1 \mathrm{mg}$ per animal in $8 \beta-\mathrm{VE}_{2}$-treated animals (data not shown). By using proliferating cell nuclear antigen immunohistochemistry and TUNEL staining, it was found that $\mathrm{E} 2$ and $8 \beta-\mathrm{VE}_{2}$ treatment caused a reduction of apoptosis and an increase in proliferation of granulosa cells of preantral follicles (Figs. 3 and 4, and Fig. 8, which is published as supporting information on the PNAS web site). The opposite was observed for vehicle and $16 \alpha-\mathrm{LE}_{2}$-treated animals, showing only few preantral proliferating follicles and several apoptotic follicles.

Ovarian protein expression of $\mathrm{ER} \alpha, \mathrm{ER} \beta$, inhibin $\alpha$, and $\mathrm{AMH}$ was investigated after treatment with vehicle, E2, and the isotype selective estrogens. In general, most of $\mathrm{ER} \alpha$ protein
A
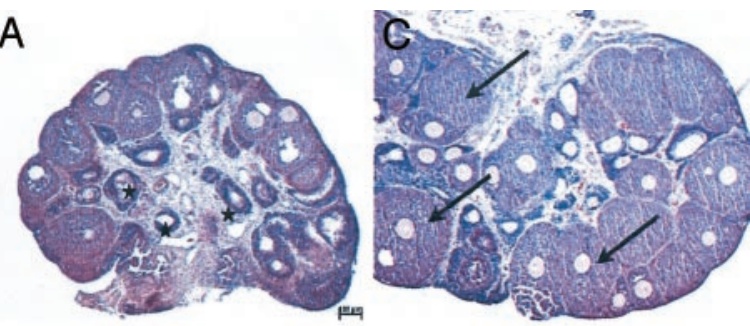

B
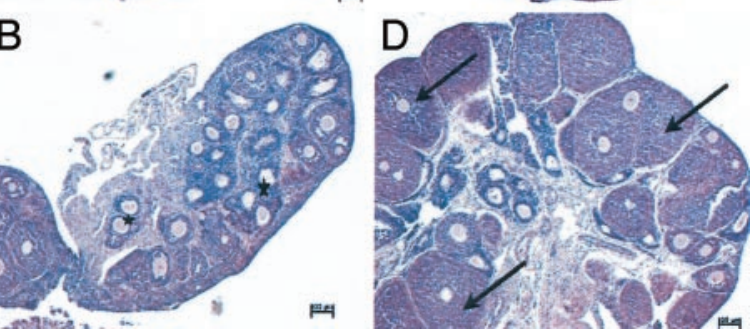

Fig. 3. Photomicrographs of ovaries from hx juvenile rats treated for 4 days s.c. with vehicle $(A), 16 \alpha-\mathrm{LE}_{2}(B), \mathrm{E} 2(C)$, and $8 \beta-\mathrm{VE}_{2}(D)$. *, atretic follicles; arrows, preantral follicles.

expression was found predominantly in the nuclei of theca cells, whereas most of $E R \beta$ protein expression was found in the nuclei of granulosa cells. The use of $\mathrm{E} 2$ and $8 \beta-\mathrm{VE}_{2}$ treatment, due to their stimulating effect on early follicular development, exhibited an increase in the immunostaining of $\operatorname{ER} \beta$, whereas vehicleand $16 \alpha-\mathrm{LE}_{2}$-treated animals showed follicles with weak $\mathrm{ER} \beta$ immunostaining in granulosa cells. In theca cells, immunostaining of ER $\alpha$ decreased after treatment with E2 (data not shown) and $8 \beta-\mathrm{VE}_{2}$, but was not influenced by the treatment with $16 \alpha-\mathrm{LE}_{2}$ (data not shown). Regarding inhibin $\alpha$ expression, it was generally observed that small follicles (types $3 \mathrm{a} / \mathrm{b}$ and 4 ) showed weak immunostaining in the cytoplasma of granulosa cells, whereas strong immunostaining was found in the cytoplasma of growing follicles (types $5 \mathrm{a} / \mathrm{b}$ and 6 ). In line with that hypothesis, E2 (data not shown)- and $8 \beta-\mathrm{VE}_{2}$-treated animals showed strong immunostaining of inhibin $\alpha$ in the follicles, whereas follicles of vehicle (data not shown)- and $16 \alpha-\mathrm{LE}_{2}-$ treated animals expressed only weak immunostaining. $\mathrm{AMH}$ showed reverse immunostaining behavior compared to inhibin $\alpha$. In general, the highest AMH expression was found in the cytoplasma of granulosa cells from small follicles (types $3 \mathrm{a} / \mathrm{b}, 4$, and $5 \mathrm{a}$ ), whereas staining intensity decreased during follicular growth. Ovarian follicles from E2 (data not shown)- and $8 \beta$ $\mathrm{VE}_{2}$-treated animals expressed decreased follicular staining intensity, whereas ovaries from vehicle (data not shown) and $16 \alpha-\mathrm{LE}_{2}$-treated animals showed strongly stained follicles.

Ovarian gene expression. The effects of $16 \alpha-\mathrm{LE}_{2}$ and $8 \beta-\mathrm{VE}_{2}(1 \mathrm{mg}$ per animal per day each) on gene expression in the ovaries of $h x$ juvenile rats were investigated by using Affymetrix microarray, Northern, and RT-PCR technologies. Cellular retinoic acid binding protein II (CRABP-II), $\alpha$-L-fucosidase (ALFUC), and inhibin $\alpha$ were found to be significantly up-regulated by E2 and $8 \beta-\mathrm{VE}_{2}$, whereas the expression of calcium-binding protein was stimulated by $16 \alpha-\mathrm{LE}_{2}$. For prostacyclin synthase (PGIS), a marked down-regulation was seen after treatment with $8 \beta-\mathrm{VE}_{2}$. A modest down-regulation of $\mathrm{ER} \alpha, \mathrm{AMH}$, and luteinizing hormone $(\mathrm{LH})$ receptor was seen after treatment with $8 \beta-\mathrm{VE}_{2}$ and E2. Interestingly, ER $\beta$ expression was found not to be regulated by treatment with the estrogens (Table 1).

Follicle staging. The total number of primary, secondary, preantral, and antral follicles were counted in GnRH antagonisttreated mice in combination with $0.3 \mathrm{mg}$ per animal of E2, $8 \beta-\mathrm{VE}_{2}$ and $16 \alpha-\mathrm{LE}_{2}$ or vehicle, respectively. The number of preantral follicles increased by more than five times, and the 

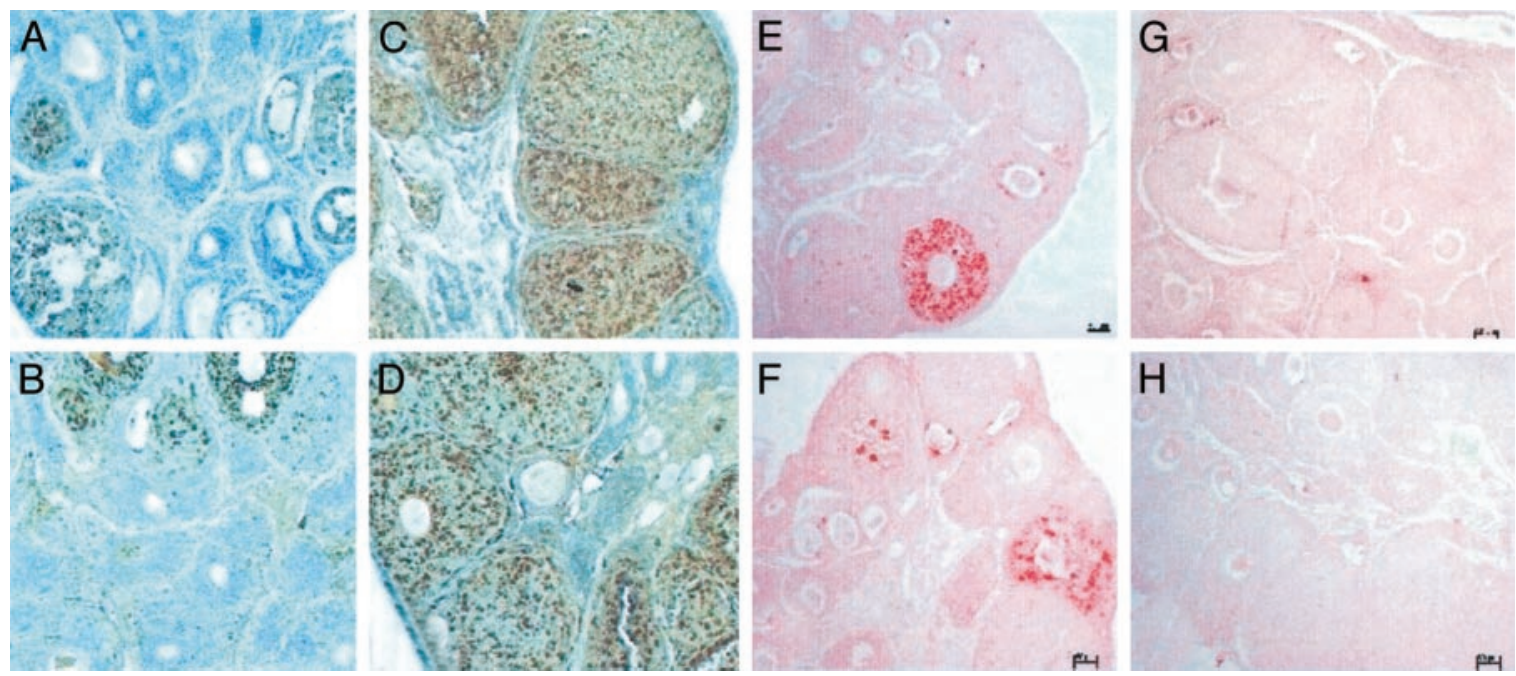

Fig. 4. Photomicrographs of proliferating cell nuclear antigen $(A-D)$ - and TUNEL $(E-H)$-stained ovaries from hx juvenile rats treated for 4 days s.c. with vehicle $(A$ and $E), 16 \alpha-\mathrm{LE}_{2}(B$ and $F), \mathrm{E} 2(C$ and $G)$, and $8 \beta-\mathrm{VE}_{2}(D$ and $H)$.

number of antral follicles was doubled after treatment with E2 and the $8 \beta-\mathrm{VE}_{2}$ (Fig. 5). In addition, the number of atretic follicles was significantly decreased in both the E2 and the $8 \beta-\mathrm{VE}_{2}$ groups. The use of $16 \alpha-\mathrm{LE}_{2}$ did not exert an effect on follicular growth and/or follicular atresia.

Effects on Late Follicular Development and Ovulation Rate in hx Juvenile Rats. When follicles of hx juvenile animals treated with E2 or the isotype-selective estrogens were stimulated with $\mathrm{PMSG} / \mathrm{hCG}$, it was found that $\mathrm{E} 2$ and $8 \beta-\mathrm{VE}_{2}$ caused a dosedependent increase in ovarian wet weight (Fig. 6). In contrast, $16 \alpha-\mathrm{LE}_{2}$ did not significantly stimulate ovarian wet weights.

The number of oocytes that ovulated after PMSG/hCG administration was increased in E2- and $8 \beta$-VE 2 -treated animals. A significant increase was found with $1 \mathrm{mg}$ per animal of $\mathrm{E} 2$ and 0.1 and $1 \mathrm{mg}$ per animal of $8 \beta-\mathrm{VE}_{2}$. The use of $16 \alpha-\mathrm{LE}_{2}$ caused a slight increase in the number of ovulated oocytes, which was not significant at any of the doses tested.

Effects on Ovulation Rate and Uterine Weight in Adult, Intact Rats. When adult rats were treated for 4 days with E2 or the isotype-selective ER agonists, ovarian weights were not modified by the different treatment groups (Fig. 7 and data not shown).

The use of E2 and $16 \alpha-\mathrm{LE}_{2}$ caused a dose-dependent inhibi- tion of the ovulation rate $\left(\mathrm{ED}_{50}<0.001 \mathrm{mg}\right.$ per animal for $\mathrm{E} 2$ and $\left.16 \alpha-\mathrm{LE}_{2}\right)$ that was associated with a decrease in serum levels of LH (data not shown). In contrast, $8 \beta-\mathrm{VE}_{2}$ caused no detectable inhibition of ovulation and no influence on LH levels (data not shown) up to a dose of $0.1 \mathrm{mg}$ per animal. A slight, but statistically significant inhibitory effect was observed at a dose of $1 \mathrm{mg}$.

The use of E2 and $16 \alpha-\mathrm{LE}_{2}$ caused a dose-dependent increase in uterine dry weight in intact adult female rats. In contrast, $8 \beta-\mathrm{VE}_{2}$ did not cause an effect on uterine weight at any of the doses tested.

\section{Discussion}

With isotype-selective ER ligands, it is for the first time, possible to unravel the biological role of $\operatorname{ER} \alpha$ and $\operatorname{ER} \beta$ on ovarian function in GnRH antagonist-treated mice and hx and intact rats.

Studies in hx rats and GnRH antagonist-treated mice demonstrate that $8 \beta-\mathrm{VE}_{2}$ causes $(i)$ stimulation of early follicular growth, (ii) reduction in follicular atresia (apoptosis), (iii) specific regulation of ovarian gene expression, and (iv) stimulation of late follicular growth accompanied by an increase in the number of ovulated oocytes. Histological evaluation of the ovaries suggests that stimulation of follicular growth induced by

Table 1. Effects of a 4-day treatment with E2 and isotype-selective estrogens on ovarian gene expression in hx juvenile rats by using Affymetrix microarray, Northern, and RT-PCR technology

E2

\begin{tabular}{|c|c|c|c|c|c|c|c|c|c|}
\hline \multirow[b]{2}{*}{ Gene product } & \multicolumn{3}{|c|}{ E2 } & \multicolumn{3}{|c|}{$16 \alpha-\mathrm{LE}_{2}$} & \multicolumn{3}{|c|}{$\gamma \beta-V t_{2}$} \\
\hline & Affymetrix & RT-PCR & $\begin{array}{c}\text { Northern } \\
\text { blot }\end{array}$ & Affymetrix & RT-PCR & $\begin{array}{c}\text { Northern } \\
\text { blot }\end{array}$ & Affymetrix & RT-PCR & $\begin{array}{c}\text { Northern } \\
\text { blot }\end{array}$ \\
\hline$C R A B P-I I$ & $>8.8$ & 32 & ND & $>1.7$ & 3.2 & ND & $>14$ & 15.9 & ND \\
\hline ALFUC & 6.6 & 5.4 & ND & 2 & 2.2 & ND & 6.1 & 5.7 & ND \\
\hline$C a B P$ & $>58$ & 72 & ND & $>4.9$ & 9.3 & ND & $>1.7$ & 1.8 & ND \\
\hline Inhibin $\alpha$ & ND & ND & 4.9 & ND & ND & 1.8 & ND & ND & 5.3 \\
\hline PGIS & -2.3 & -3.7 & ND & -2.3 & -3.6 & ND & $<-3.2$ & -11.1 & ND \\
\hline$E R \alpha$ & ND & 1.5 & ND & ND & -2 & ND & ND & -4.2 & ND \\
\hline$A M H$ & -1.5 & -2.5 & ND & 1.1 & -1.7 & ND & -1.4 & -3.3 & ND \\
\hline$L H-R$ & ND & ND & -3.1 & ND & ND & -1.5 & ND & ND & -2.4 \\
\hline$E R \beta$ & ND & 2 & ND & ND & 1.4 & ND & ND & 1.1 & ND \\
\hline Aromatase & ND & 0.8 & ND & ND & 1 & ND & ND & 0.9 & ND \\
\hline
\end{tabular}

ND, not determined 


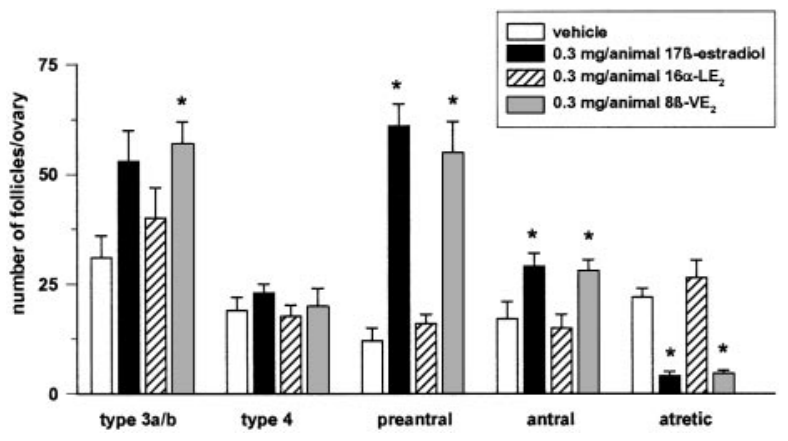

Fig. 5. Number of follicles in GnRH antagonist-treated juvenile mice after s.c. treatment for 4 days with vehicle, $\mathrm{E} 2,8 \beta-\mathrm{VE}_{2}$, and $16 \alpha-\mathrm{LE}_{2}(n=5$ animals per group). *, $P<0.05$ vs. vehicle group. Values are given as mean $\pm S D$.

the $\operatorname{ER} \beta$ agonist is due to an increase in the number of early preantral follicles (early folliculogenesis) and a decrease in follicular atresia. At the same time, a decrease in $\operatorname{ER} \alpha$ protein expression in theca cells and an increase in $\operatorname{ER} \beta$ protein expression in granulosa cells is seen in growing, preantral follicles, suggesting that $\operatorname{ER} \beta$, in contrast with $\operatorname{ER} \alpha$, is one of the key players during this period of early follicular development. Obviously, it is this specific expression pattern that governs the specific stimulatory responsiveness of early, preantral follicles to $8 \beta-\mathrm{VE}_{2}$ and $\mathrm{E} 2$, but not to $16 \alpha-\mathrm{LE}_{2}$.

The use of $8 \beta-\mathrm{VE}_{2}$ exhibits the same efficiency and a similar high potency as E2. In contrast, $16 \alpha-\mathrm{LE}_{2}$ has little or no effect, implying that direct estrogen effects on ovarian follicular development are mediated by $\mathrm{ER} \beta$. As a consequence, more follicles start to enter the preantral and antral follicle stage after $8 \beta-\mathrm{VE}_{2}$ treatment, leading to an increased number of ovulated oocytes after superovulation with PMSG and hCG, as shown in immature hx rats. Whether the improvement of follicular development also leads to an improvement of oocyte and embryo quality has to be proven in rodents and nonrodents in the future.

$\operatorname{ER} \alpha(11,23)$ and $\operatorname{ER} \beta(10,11)$ knockout mice have proven useful in understanding the role of estrogen in the ovary and uterus. $\operatorname{ER} \alpha$ knockout mice $(23,24)$ have ovaries with multiple
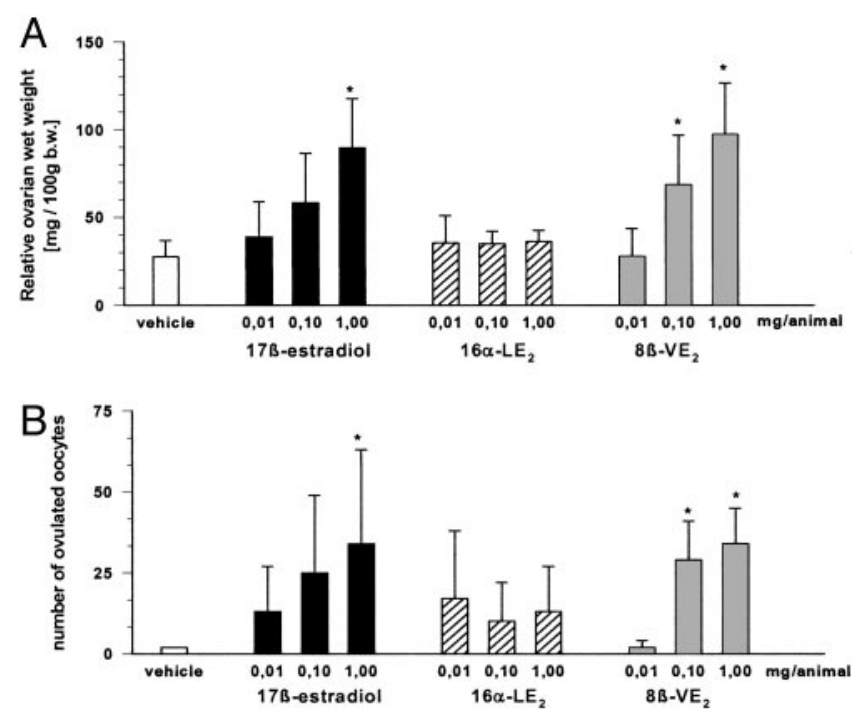

Fig. 6. Effect of vehicle, E2, $8 \beta-\mathrm{VE}_{2}$, and $16 \alpha-\mathrm{LE}_{2}$ on ovarian wet weight $(A)$ and ovulation rate $(B)$ in hx juvenile rats. Vehicle and compounds were s.c. administered daily for 4 days ( $n=6-7$ animals per group). $*, P<0.05$ vs. vehicle group. Values are given as mean \pm SD.
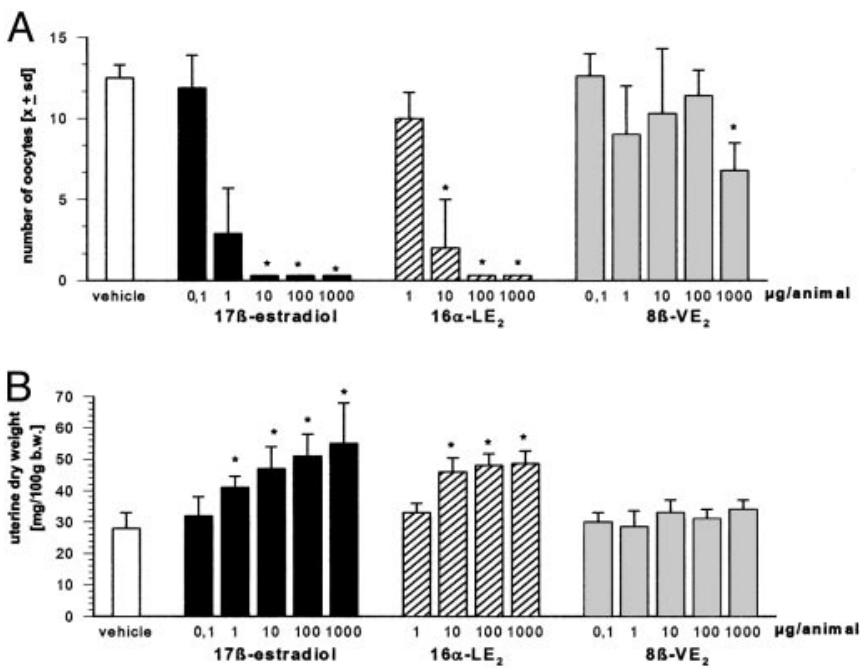

Fig. 7. Effect of vehicle, $E 2,8 \beta-\mathrm{VE}_{2}$, and $16 \alpha-\mathrm{LE}_{2}$ on ovulation rate $(A)$ and uterine dry weight $(B)$ in adult rats. Vehicle and compounds were s.c. administered daily for one ovarian cycle ( $n=8$ animals per group). ${ }^{*}, P<0.05$ vs. vehicle group. Values are given as mean \pm SD.

hemorrhagic cysts and elevated LH levels. Follicular growth and development is not compromised, but the animals are unable to ovulate and no corpora lutea are formed. $\operatorname{ER} \beta$ knockout mice $(10,11)$ also show intact follicular growth. However, their fertility is compromised, as demonstrated by reduced number of corpora lutea and reduced ovulatory capacity.

In agreement with observations in $\mathrm{ER} \alpha$ knockout mice our observations with isotype-selective ER agonists in hx rats and $\mathrm{GnRH}$ antagonist-treated mice show that $\mathrm{ER} \alpha$ is not crucial for follicular growth and development. Up to a dose of 1,000 $\mu \mathrm{g}$ per animal, the $\operatorname{ER} \alpha$ agonist was not able to stimulate ovarian growth and early folliculogenesis. Furthermore, an ovulation inhibiting effect was shown by the $\operatorname{ER} \alpha$ agonist. On the basis of the generally low expression of $\mathrm{ER} \alpha$ in the ovarian theca cells and the pronounced expression of $\operatorname{ER} \alpha$ in the pituitary $(6,7)$, it is most likely that the $\mathrm{ER} \alpha$ agonist causes its effect on ovulation inhibition by means of an action on the hypothalamic-pituitary axis rather than by a paracrine effect through ER $\alpha$ in theca cells. This result is substantiated by the data in the classical ovulation inhibiting assay in the adult intact rat where the observed ovulation inhibiting effect is associated with decreasing $\mathrm{LH}$ levels (data not shown). Furthermore, the findings in rats are dose-dependent and occur at rather low doses of the ER $\alpha$ agonist ( $\geq 10 \mu \mathrm{g}$ per animal). Our findings on ovulation cannot be compared with the ovarian phenotype in $\mathrm{ER} \alpha$ knockout mice, because those animals showed secondary hormonal imbalances such as elevated serum concentrations of LH that hinder comparison to our own data.

Concordant with observations in $\mathrm{ER} \beta$ knockout mice our findings in $\mathrm{PMSG} / \mathrm{hCG}$-treated hx rats show that $\mathrm{ER} \beta$ supports ovulation by a direct ovarian action. However, regarding folliculogenesis, our findings are in contrast to those in $\mathrm{ER} \beta$ knockout mice (undisturbed follicular development) and clearly show that not $\mathrm{ER} \alpha$ but $\mathrm{ER} \beta$ plays an important role in modulating early folliculogenesis in GnRH antagonist-treated mice and hx rats.

E2 originates from the ovary, intraovarian concentrations amounting to up to $5 \mu \mathrm{mol} /$ liter during the menstrual cycle (25). At the site of origin, E2 acts directly on folliculogenesis. High doses of exogenous E2 ( $\geq 0.1 \mathrm{mg}$ per animal per day) and of the $8 \beta-\mathrm{VE}_{2}$ ( $\geq 1 \mathrm{mg}$ per animal per day) are, therefore, required to significantly stimulate ovarian growth in the absence of pituitary derived hormones (follicle-stimulating hormone, prolactin, and 
growth hormone) in hx rats and $\mathrm{GnRH}$ antagonist-treated mice. Such quantities may saturate and activate any cognate receptors, $\mathrm{ER} \beta$ being expressed at high levels in the granulosa cells of growing follicles. Slight increases observed in ER $\beta$ mRNA and protein levels after treatment with $\mathrm{E} 2$ and $8 \beta-\mathrm{VE}_{2}$ could be referable to the increase in size of the growing follicles. The up-regulation of ER $\beta$ expression is accompanied by a slight decrease in $\mathrm{ER} \alpha$ mRNA and protein as well as an up-regulation of inhibin $\alpha$ and down-regulation of AMH mRNA and protein expression, two classical granulosa cell proteins known to play an important role in follicle growth, differentiation, and/or follicle recruitment $(26,27)$.

Affymetrix analysis reveals the expression of a considerable number of genes to be strongly modulated in the ovary by treatment of juvenile hx rats with $\mathrm{E} 2$ and $8 \beta-\mathrm{VE}_{2}$, among these CRABP-II, ALFUC, and PGIS. In contrast, the expression of calcium-binding protein-9k is stimulated by $\mathrm{E} 2$ and $16 \alpha-\mathrm{LE}_{2}$, whereas $8 \beta-\mathrm{VE}_{2}$ only slightly affects the mRNA level of calciumbinding protein-9k.

CRABP-II is a binding protein of the vitamin A-derivative retinoic acid, a key modulator controlling differentiation and proliferation of epithelial cells. It could be assumed that estrogen induced induction of CRABP-II leads to a restriction of available retinoic acid action during granulosa cell proliferation. The expression of CRABP-II in rat ovarian granulosa cells has been described (28).

ALFUC is an hydrolytic enzyme catalyzing the hydrolysis of terminal $\alpha$-L-fucosidase linkages in glycosphingolipids and glycoproteins (29). Considering that cell-cell recognition involved in tissue differentiation and development is modulated by changes in the sugar chains of surface glycoproteins, and that deletion of $\alpha$-fucosyl residues is one of such modulations, ALFUC can be assumed to play a role in tissue differentiation and development taking place during the process of cyclic recruitment, proliferation, and maturation of ovarian follicles.

Prostacyclin, the product of PGIS, is a potent endothelial vasodilator, the level of which is modulated by steroid hormones

1. Smith, E. P., Boyd, J., Frank, G. R., Takahashi, H., Cohen, R. M., Specker, B., Williams, T. C., Lubahn, D. B. \& Korach, K. S. (1994) N. Engl. J. Med. 331, 1056-1061.

2. Ciocca, D. R. \& Vargas Roig, L. M. (1995) Endocrinol. Rev. 16, 35-62.

3. Kuiper, G. G., Carlsson, B., Grandien, K., Enmark, E., Häggblad, J., Nilsson, S. \& Gustafsson, J.-A. (1996) Endocrinology 138, 863-870.

4. Mosselman, S., Polman, J. \& Dijkema, R. (1996) FEBS Lett. 392, 49-53.

5. Tremblay, G. B., Tremblay, A., Copeland, N. G., Gilbert, D. J., Jenkins, N. A., Labrie, F. \& Giguere, V. (1997) Endocrinology 11, 353-365.

6. Nilsson, S., Mäkelä, S., Treuter, E., Tujague, M., Thomsen, J., Andersson, G., Enmark, E., Pettersson, K., Warner, M. \& Gustafsson, J.-Å. (2000) Physiol. Rev. 81, 1535-1565.

7. Pettersson, K. \& Gustafsson, J. Å. (2001) Annu. Rev. Physiol. 63, 165-192.

8. Kuiper, G. G., Enmark, E., Pelto-Huikko, M., Nilsson, S. \& Gustafsson, J.-A. (1996) Proc. Natl. Acad. Sci. USA 93, 5925-5930.

9. Saunders, P. T., Millar, M. R., Williams, K., Macpherson, S., Harkiss, D., Anderson, R. A., Orr, B., Groome, N. P., Scobie, G. \& Fraser, H. M. (2000) Biol. Reprod. 63, 1098-1105.

10. Krege, J. H., Hodgin, J. B., Couse, J. F., Enmark, E., Warner, M., Mahler, J. F., Sar, M., Korach, K. S., Gustafsson, J.-A. \& Smithies, O. (1998) Proc. Natl. Acad. Sci. USA 95, 15677-15682.

11. Dupont, S., Krust, A., Gansmuller, A., Dierich, A., Chambon, P. \& Mark, M. (2000) Development (Cambridge, U.K.) 127, 4277-4291.

12. Zelinski-Wooten, M. B., Hess, D. L., Wolf, D. P. \& Stouffer, R. L. (1994) Fertil. Steril. 61, 1147-1155.

13. Palter, S. F., Tavares, A. B., Hourvitz, A., Veldhuis, J. D. \& Adashi, E. Y. (2001) Endocr. Rev. 22, 389-424.

14. Richards, J. S. (1994) Endocr. Rev. 15, 725-751.

15. Harris, H. A., Katzenellenbogen, J. A. \& Katzenellenbogen, B. S. (2002) Endocrinology 143, 4172-4177.

16. Meyers, M. J., Sun, J., Marriner, G. A., Katzenellenbogen, B. S. \& Katzenellenbogen, J. A. (2001) J. Med. Chem. 44, 4230-4251. in the pregnant uterus and the ovarian cycle $(30,31)$. Estrogen modulation of PGIS in the ovary has not been described so far. Taking into account that angiogenesis is strictly controlled during the follicular phase of the ovarian cycle, to avoid; e.g., penetration of serum factors into the follicular fluid, one could speculate that down-regulation of PGIS through activation of the ER could be essential to protect proliferating ovarian follicles.

In contrast to the ovary, the ER $\alpha$ is the dominant ER expressed in the uterus, whereas $\mathrm{ER} \beta$ is expressed in the uterus at very low levels $(6,7)$. Consequently, estrogen does not induce DNA synthesis and uterine growth in $\mathrm{ER} \alpha$ knockout mice (24), in contrast to $\mathrm{ER} \beta$ knockout mice that respond fully to E2 (10). The observations in knockout mice are in line with our findings with isotype-selective ER ligands in $\mathrm{hx}$ and adult rat. It is shown that $8 \beta-\mathrm{VE}_{2}$, in contrast with $\mathrm{E} 2$ and $16 \alpha-\mathrm{LE}_{2}$, does not exhibit a detectable effect on uterine weight in intact rats. Only in immature rats was $8 \beta-\mathrm{VE}_{2}$, at doses of $\geq 0.1 \mathrm{mg}$ per animal, able to stimulate uterine growth, which may be attributable to the low but detectable affinity of $8 \beta-V E_{2}$ to $E R \alpha$. Recent rat studies with a synthetic isotype selective $\mathrm{ER} \alpha$ ligand (15) further illustrates that the uterine stimulating potential of estrogens is mediated by $\operatorname{ER} \alpha$.

Based on the presented data documenting direct stimulatory effects on the rodent ovary, we suggest that $\operatorname{ER} \beta$ agonists might be useful as a new therapeutic approach to improve ovarian function in sub- or infertile women. Ovarian infertility is seen as a health problem of increasing importance, specifically in Western societies, mainly due to an increase in the average age of women who decide to get pregnant for the first time (32), and to pathological conditions like the polycystic ovary syndrome (33). Whether substitution with an $\mathrm{ER} \beta$-selective agonist could be suitable to improve follicular quality and, as a consequence oocyte and embryo development in humans, without interfering with the endogenous menstrual cycle and the secretion of pituitary hormones, is a matter of future preclinical and clinical research.

We thank Angelika Esch, Lam-Quoc Cam, Baerbel Bragulla, Natascha Manovski, and Brigitte Brandt for assistance with animal procedures, and Lucienne Konrath for immunohistochemistry and TUNEL.

17. Harris, H. A., Albert, L. M., Leathurby, Y., Malamas, M. S., Mewshaw, R. E., Miller, C. P., Kharode, Y. P., Marzolf, J., Komm, B. S., Winneker, R. C., et al. (2003) Endocrinology 144, 4241-4249.

18. Peters, O., Hillisch, A., Thieme, I., Elger, W., Hegele-Hartung, C., Kollenkirchen, U., Fritzemeier, K.-H. \& Patchev, V. (2000) Eur. Patent 01/04290.

19. Hsu, S. M., Raine, L. \& Fanger, H., (1981) J. Histochem. Cytochem. 29, 577-580.

20. Krusche, C. A., Herrler, A., Classen-Linke, I., Hegele-Hartung, C., von Rango, U. \& Beier, H. M. (2000) Mol. Hum. Reprod. 6, 726-734.

21. Pederson, T. \& Peters, H. (1968) J. Reprod. Fertil. 17, 555-557.

22. Lockhart, D. J., Dong, H., Byrne, M. C., Follettie, M. T., Gallo, M. V., Chee, M. S., Mittmann, M., Wang, C., Kobayashi, M., Horton, H. \& Brown, E. L. (1996) Nat. Biotechnol. 14, 1675-1680.

23. Rosenfeld, C. S., Murray, A. A., Simmer, G., Hufford, M. G., Smith, M. F., Spears, N. \& Lubahn, D. B. (2000) Biol. Reprod. 62, 599-605.

24. Lubahn, D. B., Moyer, J. S., Golding, T. S., Couse, J. F., Korach, K. S. \& Smithies, O. (1993) Proc. Natl. Acad. Sci. USA 90, 11162-11166.

25. Verpoest, W. M. J. A., Cahill, D. J., Harlow, C. R. \& Hull, M. G. R. (2000) Fertil. Steril. 73, 75-77.

26. Durlinger, A. L. L., Visser, J. A. \& Themmen, A. P. N. (2002) Reproduction 124, 601-609.

27. Findlay, J. K., Drummond, A. E., Dyson, M., Baillie, A. J., Robertson, D. M. \& Ethier, J.-F. (2001) Mol. Cell. Endocrinol. 180, 139-144.

28. Zheng, W. L., Bucco, R. A., Sierra-Rievera, E., Osteen, K. G., Melner, M. H. \& Ong, D. E. (1999) Biol. Reprod. 60, 110-114.

29. Cordero, O. J., Merino, A., Paez de la Cadena, M., Bugia, B., Nogueira, M. Vinuela, J. E., Martinez-Zorzano, V. S., de Carlos, A. \& Rodriguez-Berrocal, F. J. (2001) Eur. J. Biochem. 268, 3321-3331.

30. Magness, P. R., Shideman, C. R., Habermehl, D. A., Sullivan, J. A. \& Bird, I. M. (2000) Prostaglandins Other Lipid Mediat. 60, 103-118.

31. Wu, W. X., Ma, X. H. \& Nathaniels, P. W. (1999) Am. J. Obstet. Gynecol. 180 744-779.

32. Faddy, M. J. (2000) Mol. Cell. Endocrinol. 163, 43-48.

33. Franks, S., Mason, H. \& Willis, D. (2000) Mol. Cell. Endocrinol. 163, 49-52. 